black, conspicuous, exuviae marked by a white dot surrounded by a whitish ring. $q$ scale extremely inconspicuous. No groups of ventral glands. 2 pairs of lobes. On twigs of orange seediings from Japan (Craw). In all its characters this is almost exactly like $A$. perniciosus, and would have been assumed to be that but for the locality and food-plant. It is another "physiological species,"like A. coloratus or the West Indian form of $A$. aurantii. The true perniciosus never attacks orange trees in California, nor is it found on the deciduous fruit-trees from Japan which have passed through Mr. Craw's hands, nor in Takahashi's collections.

Chionaspis difficilis, n. sp. $-q$ scale about $2 \mathrm{~mm}$. long, irregular, from round to subelongate, moderately convex, white; exuviae to one side, 2 nd skin black or nearly so, ist skin pale straw yellow. $\delta$ scale white, tricarinate. $\&$ orange-rufous, becoming bluish-green when boiled in soda. 5 groups of ventral glands, caudolaterals 43 , cephalolaterals 4I-43, median about 37 . Median lobes large, diverging; second and third lobes notched; plates spine-like, large. On Elaeagnus from Japan (Craw). This is a very Diaspis-like Chionaspis.

C. latus, n. sp.-Allied to C. braziliensis, with a tricarinate white $\delta$ scale, and a broad pyriform red-brown $q$ scale. The broad flat scale readily distinguishes it. On leaves of orange, Tokio, Japan (Takahashi).

C. bambusae, n. sp. - + scale white, elongate-pyriform, exuviae pale straw yellow, second skin with an orange spot at the tip. In size, shape and color it is like $C$. vaccinii, but it differs in the number of glands in the ventral groups, etc. On leaves of bamboo, Tokio, Japan (Takahashi).

Mytilaspis carinatus, n. sp. $-q$ scales something like $M$. citricola, but narrower and with a pronounced median longitudinal keel. 4 groups of ventral glands, of about 4 orifices each. Lobes small. Some large spine-like plates. Saccular glands along the pygidial margin. Rows of elongate pores marking the obsolete segments. On a plant like Anthurium from Central America (Craw).

M. crawii, n. sp. $-q$ scale narrow, about $2 \frac{1}{3} \mathrm{~mm}$. long and $\frac{1}{2} \mathrm{~mm}$. wide, slightly curved, pale orange yellow, exuviae concolorous. Four groups of ventral glands, caudolaterals of 3 , cephalolaterals of 4 . Median lobes very large, rounded at ends, their edges finely serrate. Beneath the epidermis of leaves of Elaeagnus from Japan (Craw).

Parlatoria theae, n. sp.- $q$ scales on bark, very inconspicuous, about $\mathrm{I}_{3}^{2} \mathrm{~mm}$. long, oval in outline, slightly convex, pale ochreous, with the and skin black or nearly so. Removed from the twig they leave a white mark. o (after boiling) colorless, lobes pale ochreous. Median lobes trilobed. 4 groups of ventral glands, with a single median one. Caudolaterals 8, cephalolaterals 20 . On tea-plant, Japan (Takahashi).

$P$. theae var. viridis $\mathrm{v}$. nov. vel $\mathrm{n}$. sp. $-q$ scale about $\mathrm{I} \frac{1}{2} \mathrm{~mm}$. long, nearly circular; but the exuviae projecting at one side. Scale white with a more or less pronounced grayish yellow tinge, exuviae dark greenish to black. o (in soda) bluish-green with the pygidial area pale orange and the region about the mouth suffused with brown. Five groups of ventral glands, caudolaterals 16 to $\mathrm{I} 7$, cephalolaterals 9 to 16 , median $I$ to 4 . On bark of twigs of an ornamental plant from Japan (Craw). The tips of the median lobes are more produced than in theae.

\title{
XI. Some Species of Oxybelus Found in New Mexico.
}

$$
\text { BY T. D. A. COCKERELL AND C. F. BAKER. }
$$

Oxybelus quadricolor, n. sp.- Female : About to $\mathrm{mm}$. long, black with red and creamy-white markings, strongly punctured. Head rather large, somewhat broader than 
long seen from in front, closely punctured, the punctures very fine and close on the face. Mandibles black, or so dark brown as to seem so. Pubescence short, and inconspicuous except on front, sordid silvery. A tubercle on vertex. Occiput simply punctate. Antennae with flagellum becoming dark reddish-brown. Thorax closely punctured; prothorax with two elongate marks on superior margin, and the tubercles, white; mesothorax with the anterior portion dull red, the red extending about as far backwards as the level of the tegulae in the median line, but laterally narrowly beyond the tegulae; on the red portion with a weak median carina. Scutellum and postscutellum each with a median carina, that on the former rather weak. Squamae yellowish-white, with the external margins semi-transparent and radiately wrinkled, the terminal points stout and gently curved. Spine quite small, concave above, rapidly narrowed to an acute point, the sides straight. Metathorax above strongly, subreticulately, obliquely ridged; median area triangular, closed above, microscopically roughened within but shining and crossed by three or four weak transverse striae, acutely angled below, passing into a rather short median carina; lateral faces striato-punctate, the striae subobsolete below, strong above. Tegulae shining orangebrown, with an opaque whitish spot on anterior half. Wings hyaline, nervures piceous, marginal cell bluntly pointed, the apex directed away from the costal margin. Legs black, spurs dark brown; middle femora with a white spot at tip beneath; middle and posterior tibiae with a short white streak at base above, anterior tibiae with a very narrow white stripe extending about two-thirds of the length from the base but sometimes obsolete. Abdomen with interrupted cream-colored bands on segments $\mathrm{I}-4$; on the first segment the band is reduced to two transversely elongate patches, somewhat further apart than the transverse diameter of either; puncturing coarse and sparse on discs of segments, fine and close about margins. Pygidium rufous.
Hab. - Santa Fe, N. M., July 6, 1895, on a white flowered Umbellifer (Ckll., 3353). The specimen had previously visited an Asclepiad, as shown by the pollen masses adherent to the legs. Another example from Fort Collins, Colorado (Baker) differs in that the spine is longer, the points of the squamae more produced, and the puncturing coarser. Another from Las Cruces, N. M. (C. Rhodes, 149).

Oxybelus heterolepis, n. sp.-Male : About $7 \mathrm{~mm}$. long, closely but rather coarsely punctured, black with yellow markings. Head about as broad as long seen from in front, strongly punctured, front and face covered with silvery pile. A slight protuberance on the vertex, but no well defined tubercle. Mandibles pale yellow except the dark tips. Antennae with the terminal half of the flagellum becoming rufous. Thorax without any red, closely punctured. Prothorax entirely black, except the pale yellow tubercles, in the middle of which is a dark (really hyaline) spot. Cheeks, pleurae and tubercles with short silvery pubescence: vertex and thorax above with short black pubescence. Scutellum and post-scutellum each with a median carina, that on the latter somewhat prominent throughout its length. Squamae with long slightly curved terminal points, semitransparent, yellowish white, separated by a distance as great as the base of either. Spine moderately elongate, narrow, practically straight, parallel sided, grooved above, brownish, with the tip rounded and entire. Metathorax reticulate above; median area short, smooth within, open above, rounded below and passing into a long median carina; lateral faces striatopunctate. Tegulae and extreme base of wings rufous, the former with an obscure whitish spot. Wings hyaline, nervures dark brown, marginal cell obliquely truncate. Legs black, with the apices of all the femora reddish yellow, the tibiae yellow externally, and the tarsi yellow becoming rufescent at ends. The yellow of the middle tibiae is at about its middle half interrupted by a 
rounded incursion of the black. Abdomen with weak lateral spines on segments $3-6$; finely punctured, shining. Broadly interrupted yellow bands on segments $1-5$, the interruption in each case takes the form of a broad wedge of black, so that the yellow marks come closest together at their distal margins, being thence obliquely truncate; this is most perceptible on the first two segments.

Hab.-Albuquerque, N. M., June 30, 1895, between the town and the University (Ckll., $3242)$.

Var. defectus n. var.-Abdominal bands reduced to spots, rounded or not obliquely truncate inwardly. The legs are darker, lighter portions inclining to rufescent in some specimens. Albuquerque (Ckll., 323 I, 3243, 3229, 3239).

O. heterolepis was taken at Albuquerque on June 30 in some numbers, almost surely on flowers of Fallugia paradoxa, though unfortunately no record was kept of this. Most nearly related to packardii. In this species, however, the spine is not at all narrowed towards the tip; the lateral faces of metathorax are very sparsely punctured and the striae strong. It also differs in the shape of the squamae and the puncturing of the abdomen. If, on the examination of larger series, the var. defectus should prove distinct, it can be separated under the varietal name.

Oxybelus trifidus, n. sp. - Male: About $4.5 \mathrm{~mm}$. long, black with dull orange markings, rather finely and closely punctured. Head about as broad as long seen from in front; front comparatively narrow, it and the face covered with silvery pile; vertex closely and roughly punctured; no tubercle. Mandibles yellow except the tips; terminal half of the flagellum rufescent. Prothorax all black, the margins of the tubercles only, slightly pallid. Mesothorax and scutellum strongly and coarsely punctured, on the mesothorax posteriorly becoming striatopunctate. Scutellum and postscutellum each with a median carina. Squamae separated by a distance less than their breadth; large, broad, white, semitransparent, with rather strong acute lateral points which are bent under the squamae and about equal their tips. Spine short and very broad, of the emarginatus type, but the emargination filled in by a broad plate, so that the spine becomes actually trifid, or one might say truncate with two notches. Metathorax above with strong oblique ridges; median area elliptical, scabrous within, passing below into a median carina of moderate length; lateral faces striato-rugose. Tegulae and extreme bases of wings orange rufous. Wings hyaline, nervures brown, marginal cell obliquely truncate. Femora black except the orangerufous tips beneath. Tibiae and tarsi dull orange-rufous, the middle and hind tibiae black on the inner side. Abdomen shining black, very closely and finely punctured, short blunt spines on lateral margins of segments 5 and 6 only. Narrow, interrupted orange bands on segments $\mathrm{r}-4$, those on 3 and 4 being linear, and very broadly interrupted. Segments I-2 silvery margined posteriorly.

Hab.-Santa Fe, N. M., Aug. I, 1895 (Ckll., 3997). This species is perhaps as nearly related to mexicanus as any. In the form of the spine and some other characters it differs from any described N. A. species.

Oxybelus coloradensis Baker.-A specimen of this species taken at Las. Cruces (Ckll., 2436), was determined as emarginatus by Mr. Fox.

Oxybelus packardii Rob.-One at Albuquerque (Ckll., 4533). This was on Cleome serrulata, Aug. 15, 1895. At that date no heterolepis were found.

Oxybelus cornutus Rob.-Las Cruces, N. M., on Solidago canadensis Aug. 24, 1894 (Ckll., 2002) and Albuquerque, N. M., June 30, I895, with heterolepis.

Oxybelus quadrinotatus Say.-Santa $\mathrm{Fe}$, July and August; variable. 

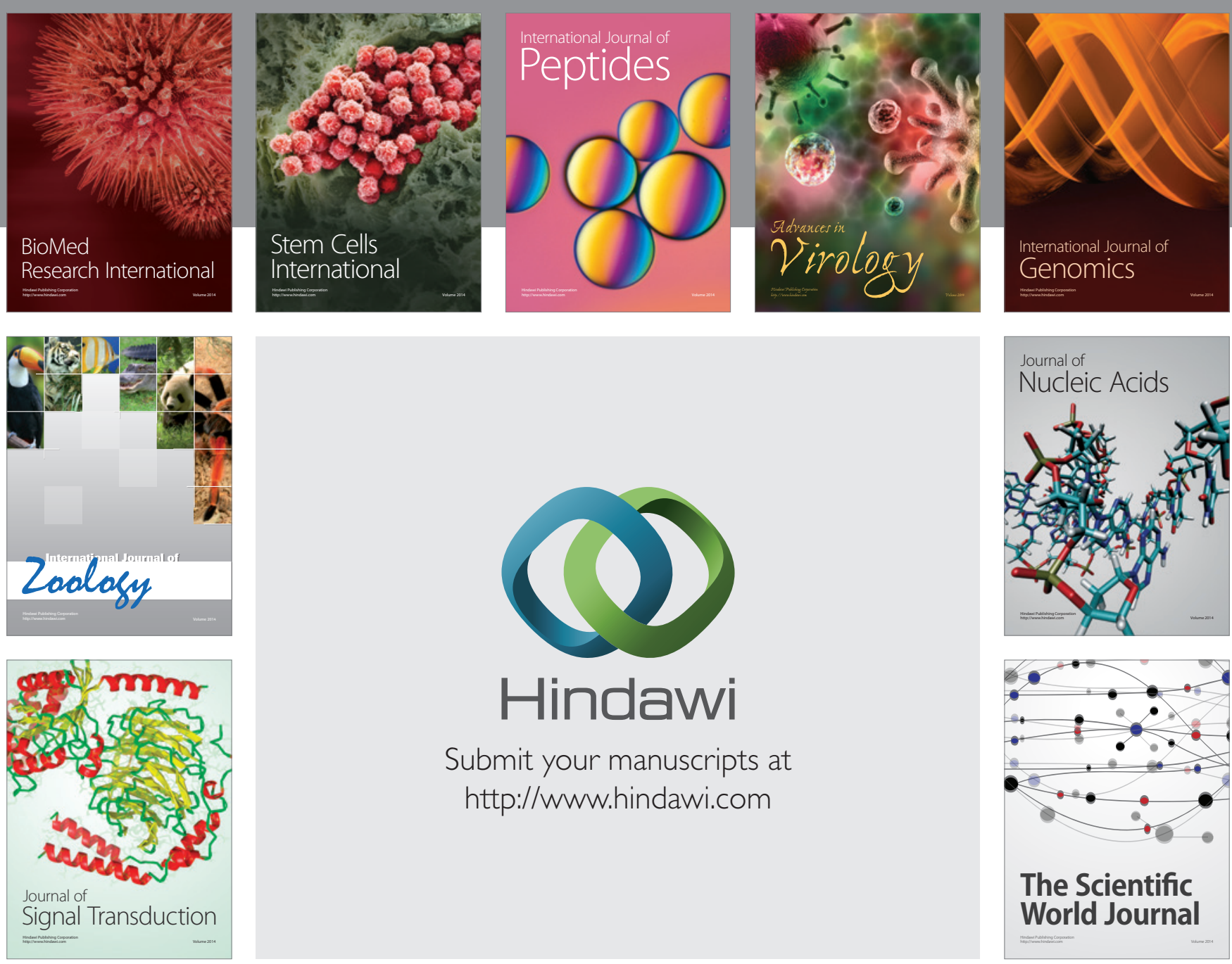

Submit your manuscripts at

http://www.hindawi.com
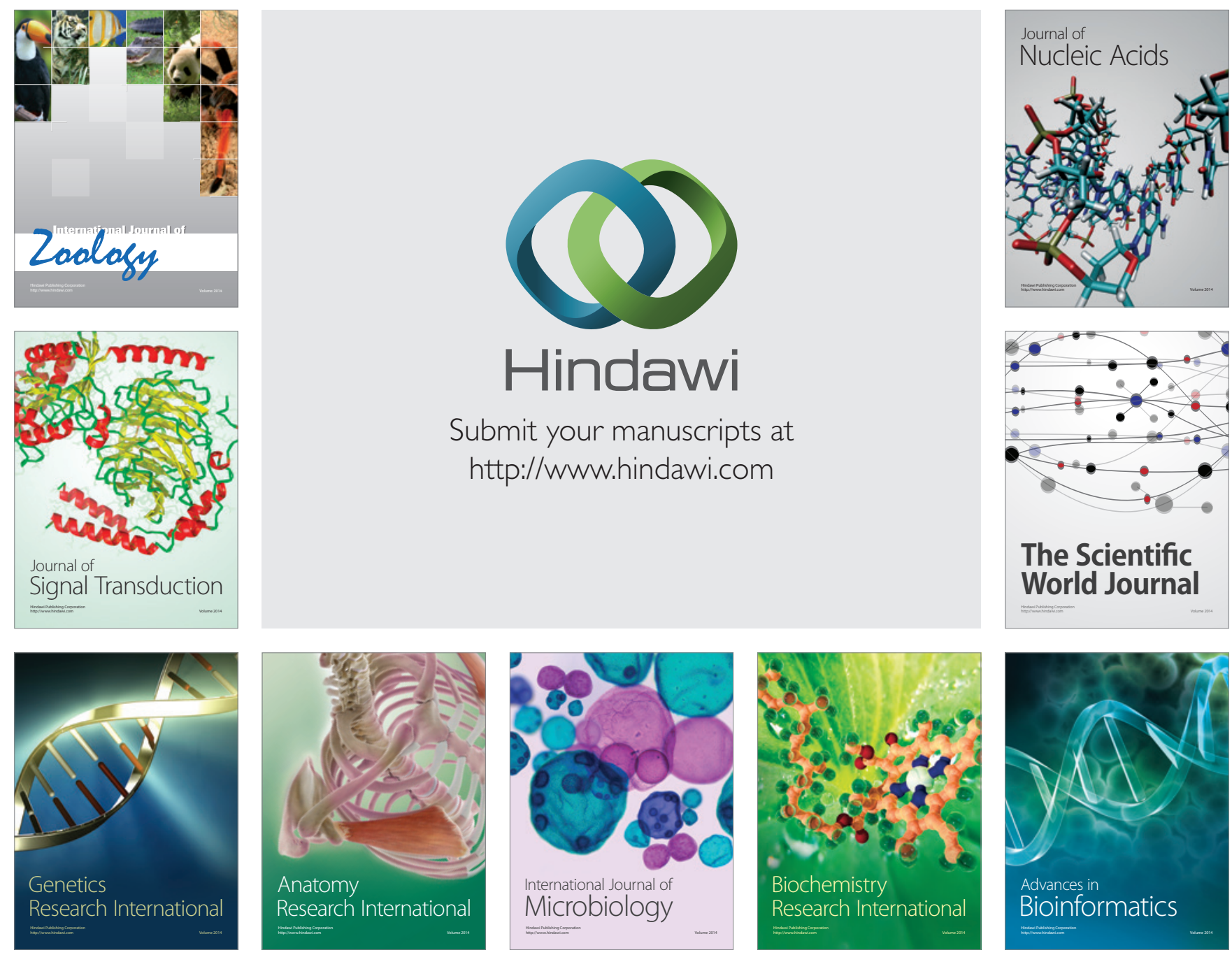

The Scientific World Journal
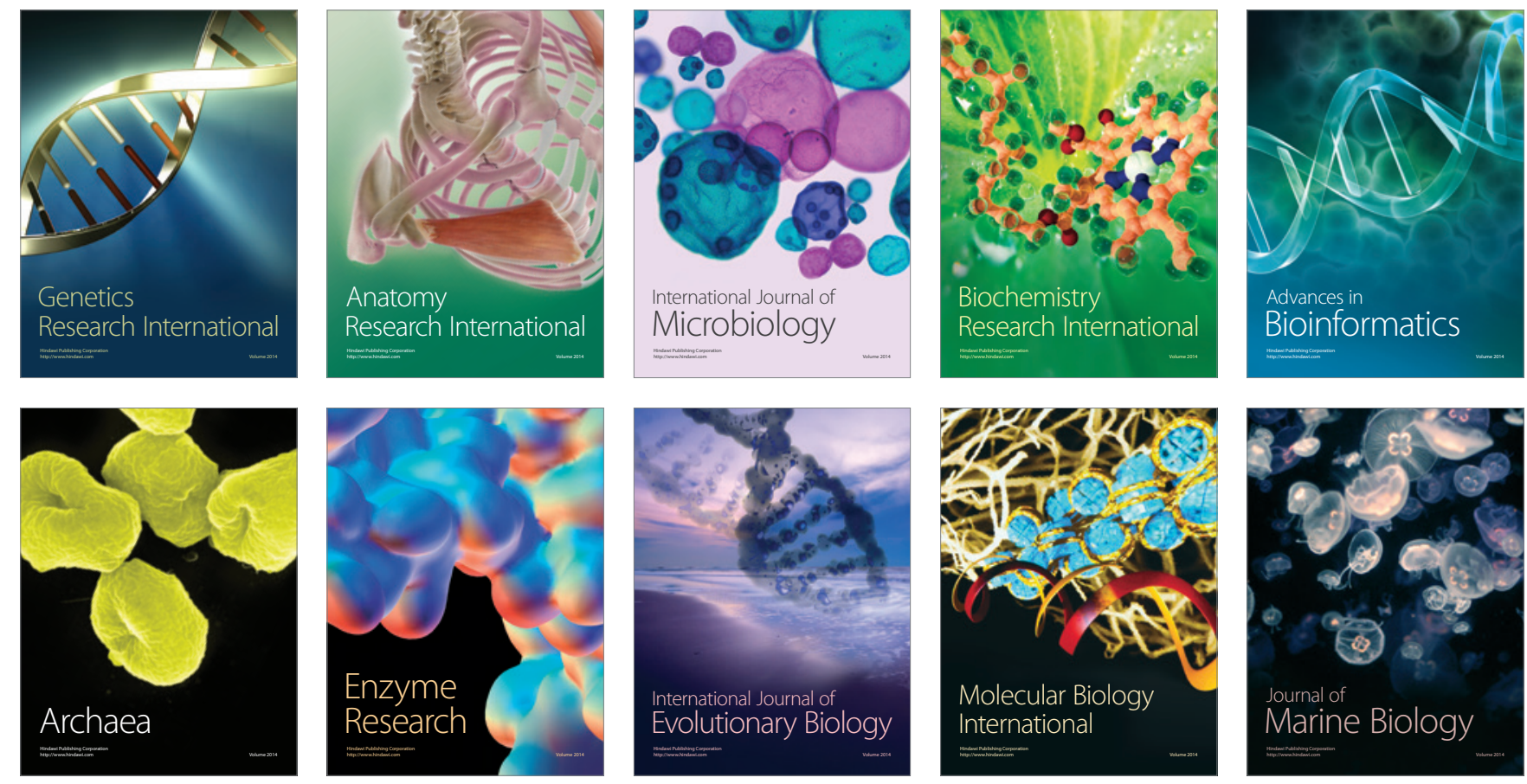